\title{
Modernisasi Manajemen Bank Sampah Melalui Pemanfaatan Aplikasi Bank Sampah IT Mobile Pada Komunitas Bank Sampah TPI BISA Kelurahan Pagak Kecamatan Beji Kab. Pasuruan
}

\author{
${ }^{1}$ Muhammad Imron Rosadi, ${ }^{2}$ Faris, ${ }^{3}$ Zainul Ahwan, ${ }^{4}$ Mulyono Wibisono \\ ${ }^{1,2}$ Universitas Yudharta Pasuruan, ${ }^{3}$ CorCom Manager PT. TIV. Pandaan \\ Email: ${ }^{1}$ imron.rosadi@yudharta.ac.id, ${ }^{2}$ faris@yudharta.ac.id, \\ ${ }^{3}$ zezen@yudharta.ac.id, ${ }^{4}$ mulyono.wibisono@danone.com
}

\begin{abstract}
:
The garbage problem in Pasuruan district has been in the emergency. This condition is caused because of garbage governance in Pasuruan Regency still use conventional method $3 P$ (collection, transport and disposal) so that it can not reduce the amount of garbage dumped to TPA considering there is no process Waste processing done. Seeing the question of the Pasuruan district government made a waste handling policy through the SDSB Program (one village waste Bank). The Government's policy was responded well by the housewives at Taman Permata Indah Village of Pagak district of Beji District in Pasuruan Regency by forming the waste bank community TPI BISA. The establishment of waste bank TPI BISA this part of the response to the government policy while seeing the problem of many unhandled garbage that affects health and hygiene of the environment as a result of the increasing Population in the area. Household waste deposits generated within 1 month less than 6 quintals and every tendency month is increasing. Waste bank TPI BISA one of the waste bank that is sufficient to exist and has succeeded in managing the environment through the management of both organic and inorganic waste. In addition, the community also conducts garbage processing in the form of interesting and unique handcraft. But on the other hand, from the success also still leave a serious problem that the management system of waste bank TPI BISA be done by manual model so that there is often an error in recording the deposit amount Garbage whose edges often make a conflict in internal management of trash banks with members or customers of trash banks. Therefore, modernization of IT-based administrative management becomes a real need needed by waste bank TPI BISA, So that waste bank TPI BISA be worthy of an example of trash bank with IT-based management of mobile that can be developed thoroughly in Pasuruan Regency.
\end{abstract}

Keyword: modernization of management, IT mobile applications, waste bank 
2 | Modernisasi Manajemen Bank Sampah...

\section{Pendahuluan}

Dalam hal persoalan sampah, Kabupaten Pasuruan adalah salah satu kota di Jawa Timur yang memiliki potensi sekaligus permasalahan terkait dengan tata kelola sampah yang cukup serius. Hal ini bisa diperkuat dari data bahwa Kabupaten Pasuruan hanya memiliki 1 (satu) tempat pembuangan akhir (TPA) yang beroperasi di Kenep Beji Pasuruan dengan kondisi overload kapasitas daya tampung sampahnya ${ }^{1}$. Maka tidak heran apabila Kabupaten Pasuruan sekarang ini dalam kondisi "darurat sampah" dimana dalam 1 hari sampah yang dihasilkan sebesar 4.700 Meter Kubik. ${ }^{2}$

\section{Gambar No 1 Kondisi Sampah di TPA Kenep Beji Pasuruan}

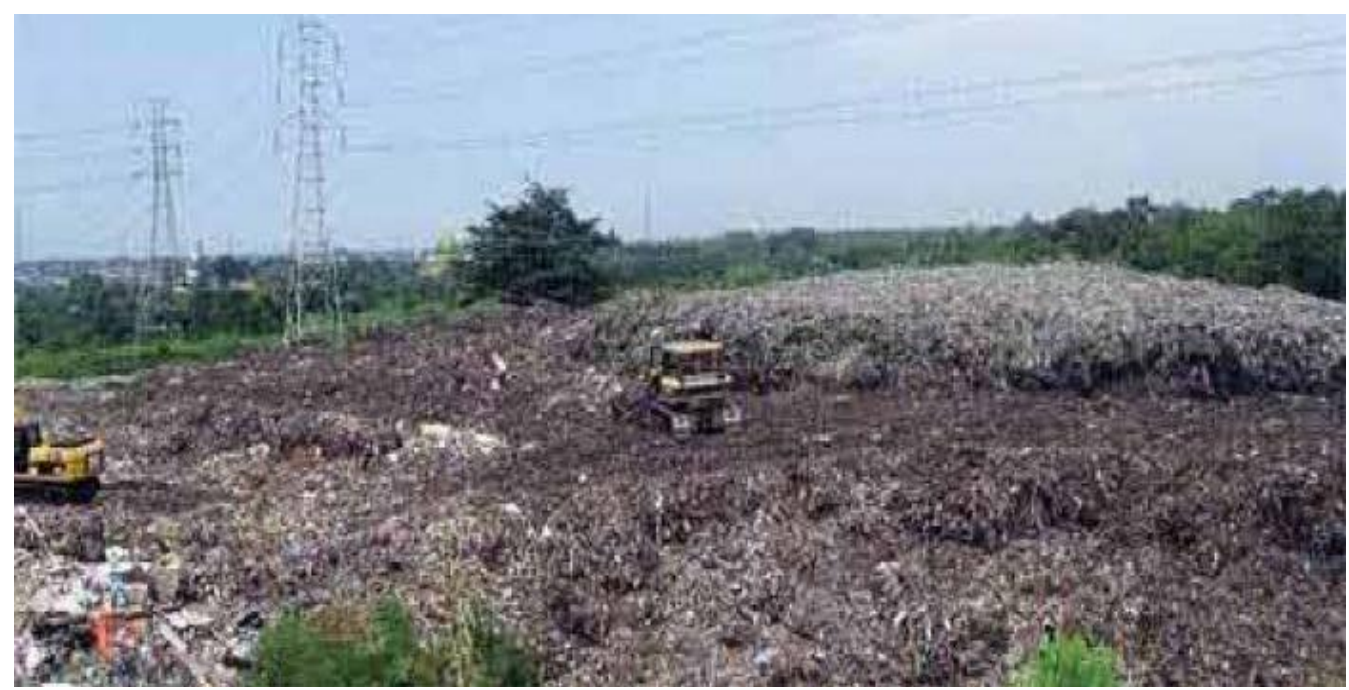

Sumber : Website Radar Bromo 2018

Over kapasitas sampah yang ada di TPA Keneb Beji ini disebabkan karena tata kelola sampah di Kabupaten Pasuruan masih menggunakan metode yang konvensional yaitu metode 3P (Pengumpulan, Pengangkutan dan Pembuangan). Metode ini hanya memindahkan sampah dari tempat penampungan sementara

\footnotetext{
1 Pemkab Pasuruan, (2016) “Tuntaskan Tpa Kenep, Bebaskan 2250 M2 Lahan"https://www.pasuruankab.go.id/berita-2077-tuntaskan-tpa-kenep-bebaskan-2250-m2lahan.html. (diakses tanggal 09 Agustus 2018)

2 Fahmi, Muhammad, (2018) "Sehari, Produksi Sampah di Kabupaten Pasuruan Capai 4.700 Meter Kubik” https://radarbromo.jawapos.com/read/2018/03/12/56305/sehari-produksi-sampah-dikabupaten-pasuruan-capai-4700-meter-kubik (diakses tanggal 09 Agustus 2018)
} 
(TPS) lantas diangkut lagi ke tempat pembuangan akhir (TPA) sehingga tidak bisa mengurangi jumlah sampah yang dibuang ke TPA mengingat tidak ada proses pengolahan sampah yang dilakukan.Melihat persoalan tersebut pemerintah Kabupaten Pasuruan telah membuat satu kebijakan mengatasi penanganan persoalan sampah ini melalui Program SDSB (Satu Desa Satu Bank Sampah). Program ini diharapkan akan mampu mengurai timbulan sampah rumah tangga dari sumbernya sehingga bisa mengurangi jumlah sampah yang dibuang ke TPA.

Hingga tahun 2017, jumlah Bank Sampah yang ada di Kabupaten Pasuruan sejumlah 35 Bank Sampah dan salah satunya adalah Bank Sampah TPI BISA di perumahan Taman Permata Indah Kelurahan Pagak Kecamatan Beji Kabupaten Pasuruan. Pendirian Bank Sampah TPI "BISA" dilatarbelakangi oleh permasalahan banyaknya sampah yang tidak tertangani sebagai akibat dari semakin bertambahnya jumlah penduduk di kelurahan Pagak Kecamatan Beji terutama di lingkungan Perumahan Taman Permata Indah. Timbulan sampah rumah tangga yang dihasilkan dari perumahan tersebut kurang lebih 6 kwintal dalam kurun waktu 1 bulan. ${ }^{3}$ Selain jumlahnya yang cukup besar persoalan sampah di kawasan tersebut juga menimbulkan bau yang cukup tidak sedap mengingat sampah hanya ditumpuk saja tanpa adanya upaya pemilahan sehingga semakin hari semakin menumpuk jumlahnya. Kondisi tersebut perlu untuk ditemukan solusinya. Atas inisiatif dari sebagian ibu-ibu rumah tangga di perumahan taman permata indah yang peduli terhadap kebersihan lingkungan maka digagaslah gerakan sosial untuk memanfaatkan barang-barang yang sudah tidak terpakai untuk dijadikan sesuatu yang bernilai. Gerakan peduli lingkungan tersebut kemudian diakomodir dalam sebuah komunitas pegiat sampah dengan kegiatan utama adalah melakukan pemilahan sampah serta melakukan pemanfaatan sampah menjadi kerajinan, kompos ecobrik dan lain-lain. Komunitas tersebut dinamakan Bank Sampah TPI BISA. Bank sampah ini bertempat di Perumahan Permata Indah Blok D-49 
4 | Modernisasi Manajemen Bank Sampah...

Kelurahan Pagak Kecamatan Beji Kabupaten Pasuruan.

Visi yang ingin dicapai oleh Bank Sampah TPI BISA adalah untuk mewujudkan kualitas lingkungan melalui bank sampah untuk mendapatkan manfaat ekonomi dan lingkungan bersih secara berkelanjutan. Visi tersebut diterjemahkan ke dalam lima (5) misi utama, yakni: (1) menyelamatkan dan peduli dengan lingkungan; (2) mengkampanyekan ke semua pihak akan pentingnya menjaga dan melestarikan lingkungan yang bersih dan sehat; (3) melakukan pemilahan sampah dari rumah tangga; (4) mengolah sampah organik dan anorganik menjadi produksi bernilai ekonomis; (5) meningkatkan kesejahteraan masyarakat dan nasabah. Program kerja utama yang sudah dijalankan selama ini oleh Bank Sampah TPI BISA adalah (1) pengumpulan sampah kering; (2) pembuatan kerajinan (handcraft); (3) pembuatan kompos.

Bank Sampah TPI BISA dalam pengelolaan sampah di kawasan perumahan Taman Permata Indah di Kelurahan Pagak cukup berhasil dan mendapatkan apresiasi dari pemerintah Kelurahan Pagak dan Dinas Lingkungan Hidup dengan diberikannya moda angkut sampah berupa kendaraan roda tiga.Namun disisi lain, dari keberhasilan tersebut juga masih menyisakan persoalan yang cukup serius pada Sistem Administrasi Pengelolaan Bank Sampah. Sistem administrasi di Bank Sampah TPI BISA dilakukan secara manual sehingga seringkali terjadi kesalahan dalam pencatatan jumlah setoran sampah yang ujung-ujungnya membuat konflik diinternal pengelola bank sampah dengan anggota/nasabah bank sampah. Pencatatan manual memang lebih membutuhkan banyak tenaga karena dalam teksnis pelaksanaannya harus mengentri data di dua buku catatan transaksi bank sampah yaitu 1 (satu) buku untuk managemen bank sampah yang 1 (satu) buku lagi untuk nasabah. 
Gambar No 2 Sistem Admisintrasi Manual Bank Sampah TPI BISA

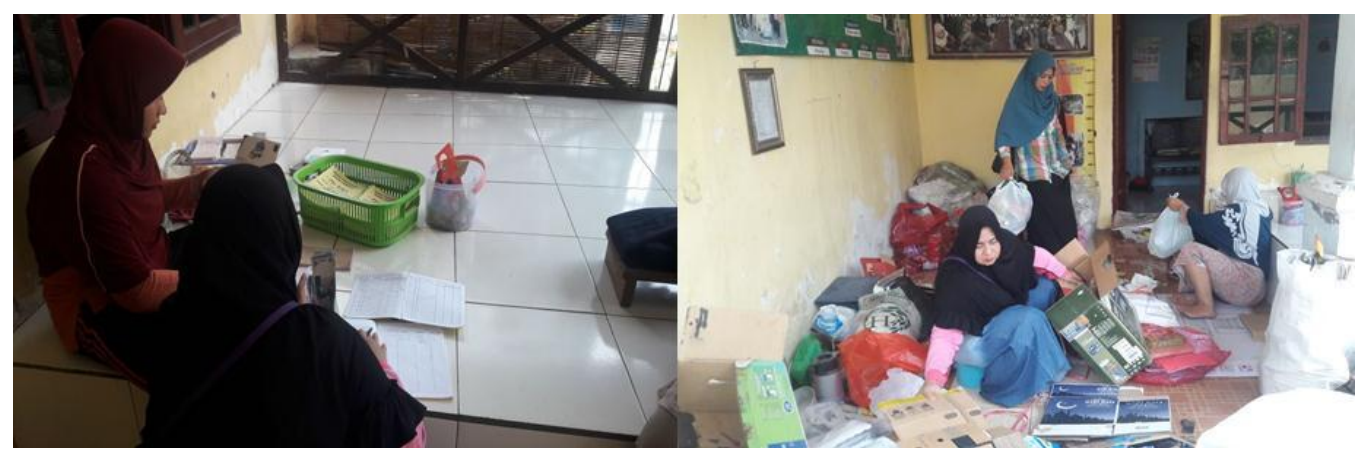

Sumber : Bank Sampah TPI BISA 2018

Keterbatasan tersebut tentunya menjadi penghambat perkembangan bank sampah TPI BISA. Untuk itu, perlu adanya upaya pendampingan modernisasi manajemen bank sampah yang lebih mendorong inovasi dan akuntabilitas sehingga peranan bank sampah bisa semakin berkualitas, berdampak dan terlihat nyata hasilnya, salah satunya dengan memanfaatkan perkembangan teknologi informasi dan komunikasi (TIK) dalam hal manajemen administrasi Bank Sampah TPI BISA. Keberhasilan program ini nantinya akan berdampak positif terhadap perkembangan internal Bank Sampah TPI BISA sekaligus menjadi bank sampah percontohan di Kabupaten Pasuruan yang akan memberikan inspirasi pada bank sampah lain di Kab. Pasuruan. 
6 | Modernisasi Manajemen Bank Sampah...

Gambar 3 Kondisi Desa Dampingan dan Proyeksi Program

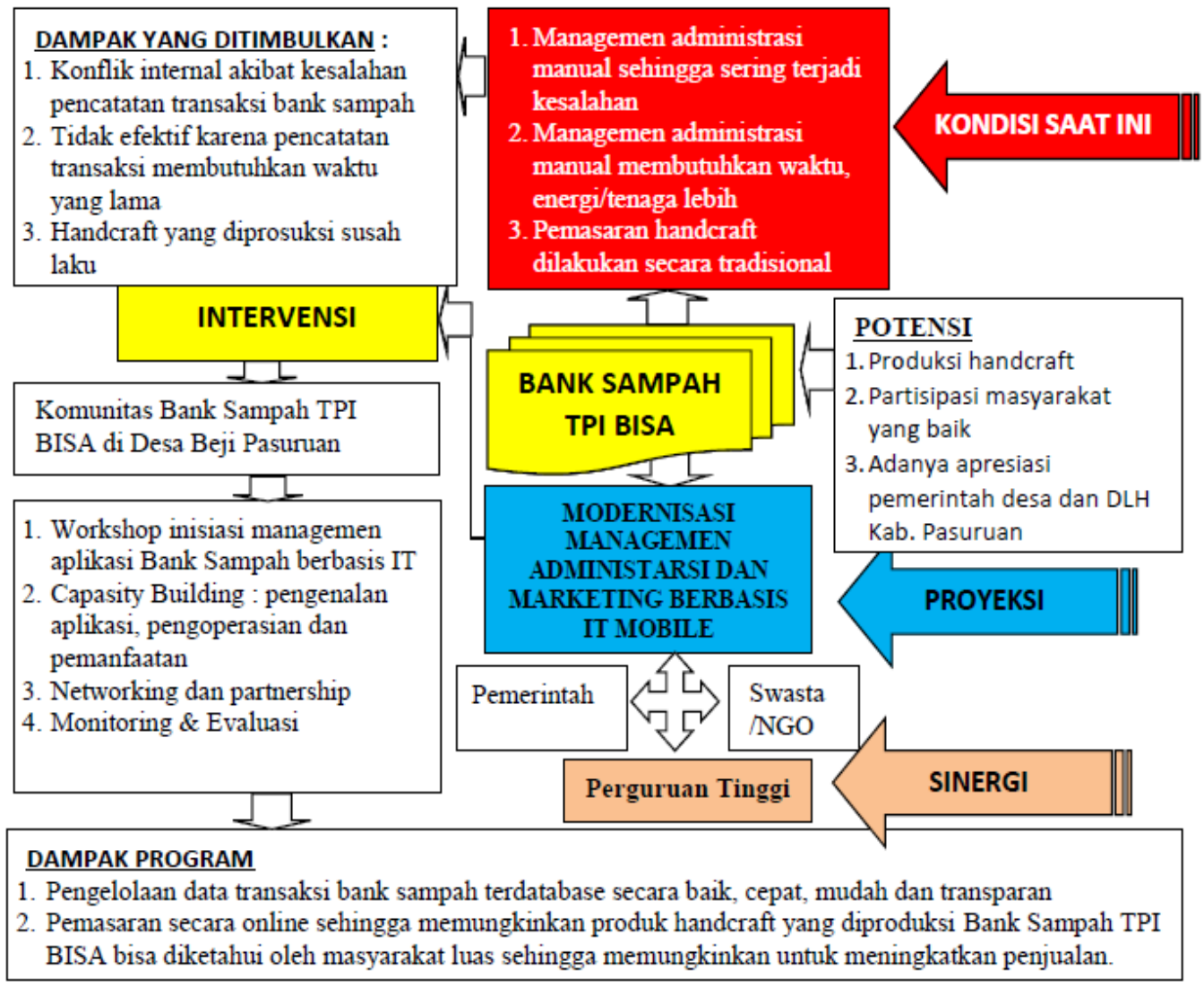

Sumber : Tim PKM 2018

\section{Metode}

Metode yang digunakan dalam program ini sebagaimana berikut:

Kegiatan pengabdian kepada msyarakat ini dimulai dengan melakukan penelitian pendahuluan terkait dengan potensi serta problem yang dihadapi oleh calon mitra program. Penelitian pendahuluan dalam pengabdian ini telah dilakukan pada bulan Juni 2018 dengan metode penggumpulan melalui Focus Group Discussion (FGD) yang melibatkan pengus Bank Sampah TPI Bisa. Adapun proses tahapan dalam pelaksanaan program sebagaimana berikut :(1)Start. Tahapan awal berupa tahapan persiapan program PKM yang didalamnya berupa pengurusan perizinan kegiatan PKM, komunikasi dan koordinasi dengan mitra program terkait, kesepakatan 
kerjasama dalam pelaksanaan program PKM;(2) Input. Tahapan ini merupakan tahapan inisiasi pelaksanaan program dalam bentuk workshop inisiasi atau $F G D$ yang mencoba membahas hasil data penelitian pendahuluan sebagai baseline yang dijadikan input untuk merancang program PKM yang dilaksanakan;(3)Proses. Tahapan ini adalah tahapan implementasi dari solusi yang telah ditetapkan untuk menyelesaikan masalah/potensi yang dialami oleh mitra program melalui peningkatan kapasitas (Capasitybuilding) dalam bentuk workshop/pelatihan, melakukan instalasi dan perancangan sistem aplikasi bank sampah berbasis IT, melakukan pendampingan serta membangun jaringan multi pihak guna mensukseskan program PKM;(4). Out put. Tahapan ini adalah tahapan akhir dari program PKM yang dilaksanakan dengan capaian 2 model out put program berupa metode dan produk. Out put metode berupa peningkatan kapasitas managemen Bank Sampah TPI BISA berbasis IT dan out put produk berupa jurnal Ilmiah dan publikasi berita.

Secara detail metode/teknis langkah-langkah dalam pelaksanaan kegiatan pengabdian masyarakat sebagaimana berikut:

Gambar no 4. Diagram Metode Pelaksanaan Program

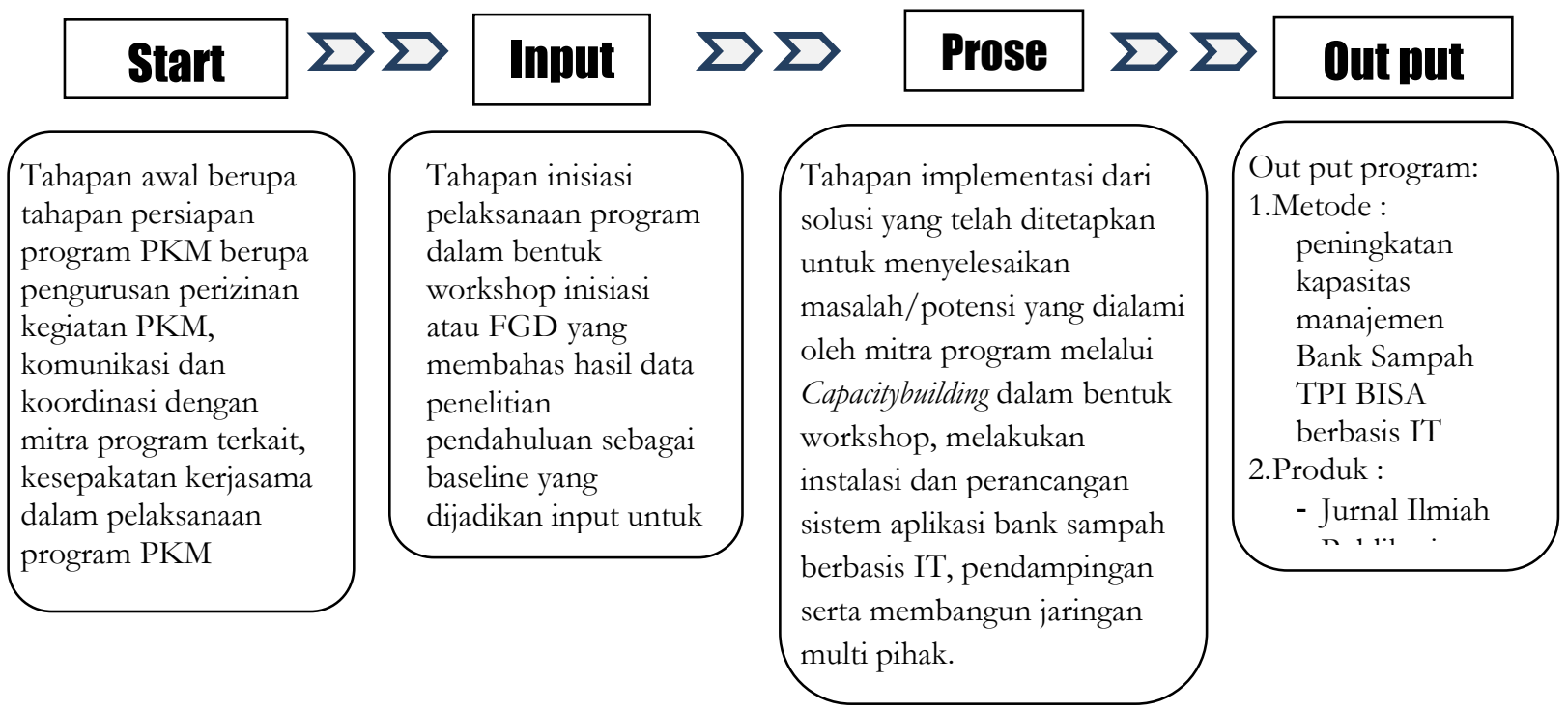


8 | Modernisasi Manajemen Bank Sampah...

\section{Hasil dan Diskusi}

\section{Penyajian Data program PKM}

\subsection{Pelatihan Pengenalan dan Penggunaan Aplikasi BankSampah IT untuk Pengurus Bank Sampah}

Pelatihan ini dilaksanakan pada 27 Juni 2019 bertempat di kantor bank sampah TPI BISA dengan melibatkan semua pengurus. Dalam pelatihan ini, semua peserta diwajibkan untuk menggunakan smartphone yang bisa terkoneksi dengan jaringan internet mengingat pelatihan ini berhubungan dengan pemanfaatan aplikasi bank sampah berbasis web maupun mobile. Merekadikenalkan dengan berbagai fitur dan fasilitas yang dapat dimanfaatkan oleh para pengurus Bank Sampah TPI BISA dalam tata kelola sampah mulai dari cara pendaftaran akun, cara login ke sistem, penambahan nasabah dan transaksi, menambahkan kategori sampah serta menambahkan album kegiatan kedalam sistem aplikasi.

Melalui pemanfaatan teknologi ini pengurus banksampah TPI BISA telah memiliki akun pada aplikasi www.banksampah.idserta Smash Bank sampah. Melalui akun ini diharapkan mulai meninggalkan model pengelolan administrasi secara manual sebagaimana yang telah dilakukan sebelumnya yang sering terjadi kesalahan dalam pencatatan serta beban kerja yang bertumpuk-tumpuk karena harus melakukan pencatatan di buku tabungan nasabah, kwitansi serta buku tabungan induk yang dimiliki oleh pengurus. Dari pelatihan pengenalan dan penggunaan aplikasi ini, pengurus bank sampah merasa terbantu karena bisa melakukan kegiatan entri data secara bersama-sama dengan pengurus yang lain sehingga meningkatkan kebersamaan dalam tim serta data yang diunggah bersifat transparan dan akuntabel yang bisa diakses semua pengurus maupun nasabah. Secara keseluruhan pelatihan berjalan secara lancar hanya saja karena peserta pelatihan adalah ibu-ibu rumah tangga yang relatif agak tua sehingga penyampaian materi dilakukan dengan menggunakan metode paktek secara langsung. 
Gambar no 5 pelatihan managemen sampah berbasis IT bagi pengurus Bank Sampah

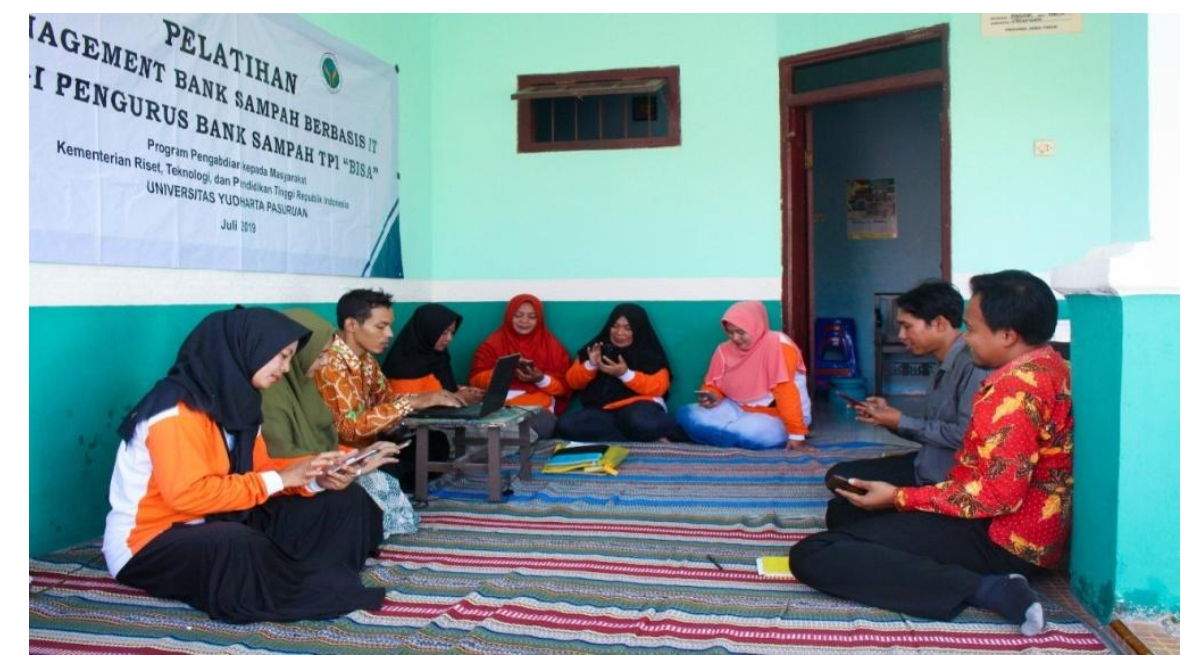

\subsection{Pelatihan Pengenalan dan penggunaan aplikasi bank sampah IT untuk nasabah}

Sebagai upaya untuk menunjang keberhasilan pengurus bank sampah dalam memanfaatkan aplikasi berbasis web dan android untuk pengelolaan administrasi kegiatan Bank Sampah maka tim pengabdian masyarakat melakukan kegiatan pengenalan dan penggunaan aplikasi bank sampah berbasis android pada nasabah bank sampah TPI BISA. Kegiatan tersebut dilaksanakan pada tanggal 10 Juli 2019 bertempat di perumahan permata indah dengan melibatkan 81 anggota nasabah bank sampah TPI BISA. Dalam pelatihan tersebut tim pengabdian masyarakat memberikan gambaran tentang keuntungan dengan menggunakan sistem aplikasi bank sampah berbasis android tersebut mulai dari data yang transparan, akuntabel serta bisa diakses recara realtime sehingga nasabah tidak perlu khawatir tentang jumlah sampah yang disetor, harga sampah perkilo serta saldo nasabah karena bisa dilihat oleh pengurus maupun nasabah. Penggunaan aplikasi ini menjadi sesuatu yang baru bagi anggota bank sampah TPI bisa mengingat selama ini masih menggunakan 
10 | Modernisasi Manajemen Bank Sampah...

sistem pencatatan secara manual yang sering menimbulkan masalah karena kesalahan pencatatan transaksi sampah. Pada bulan Agustus 2019 ini telah masuk 81 nasabah dalam sistem aplikasi SMASH bank sampah dan www.banksampah.id.

Gambar no 6 Pelatihan Manajemen Sampah IT untuk nasabah

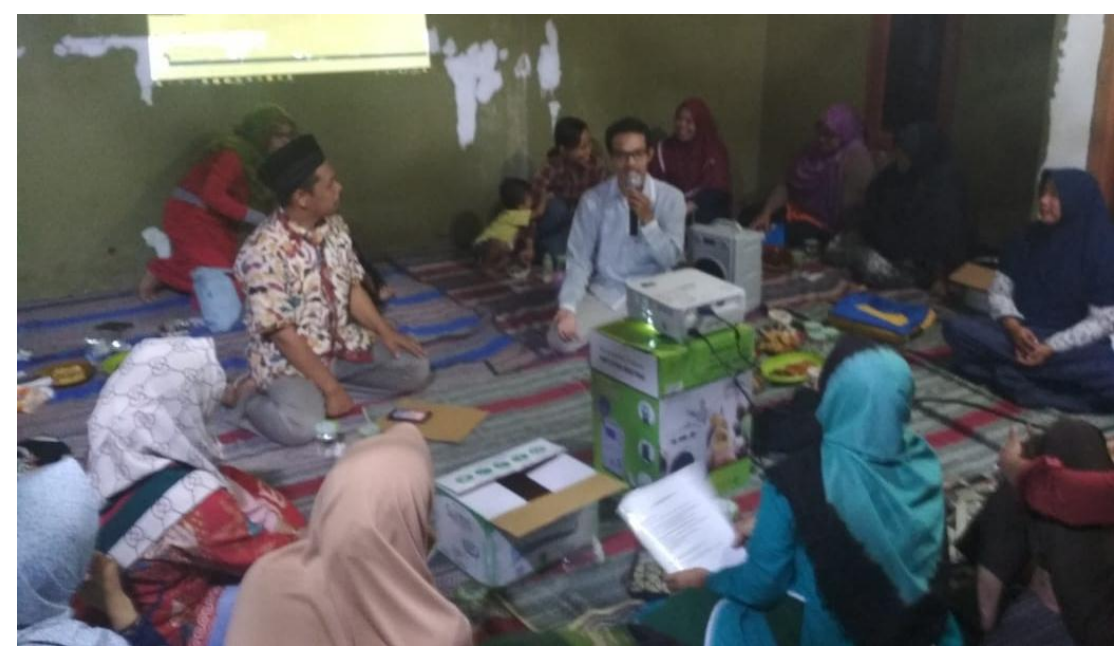

Sumber : Tim PKM UYP 2019

\subsection{Pendampingan input data transaksi sampah}

Untuk memastikan kegiatan pendampingan masyarakat dalam hal penggunaan aplikasi bank sampah bisa berjalan dengan baik, pada 25 Juli 2019 dimulai dilakukan pendampingan penginputan data transaksi sampah yang dilakukan oleh pengurus bank sampah. Kegiatan ini membutuhkan waktu yang cukup lama antara 2-3 hari mengingat jumlah transaksi yang sudah cukup banyak mulai dari awal berdirinya bank sampah TPI BISA. Dengan melibatkan semua tim pengurus entri data dilakukan mulai dari data nasabah, tanggal transaksi, jumlah dan jenis sampah serta nominal saldo dimasing-masing nasabah. Dari hasil pendampingan ini telah kelihatan peningkatan jumlah nasabah, jumlah sampah yang telah terkumpul serta saldo bank sampah. 
Gambar no 7 data transaksi Bank sampah TPI BISA
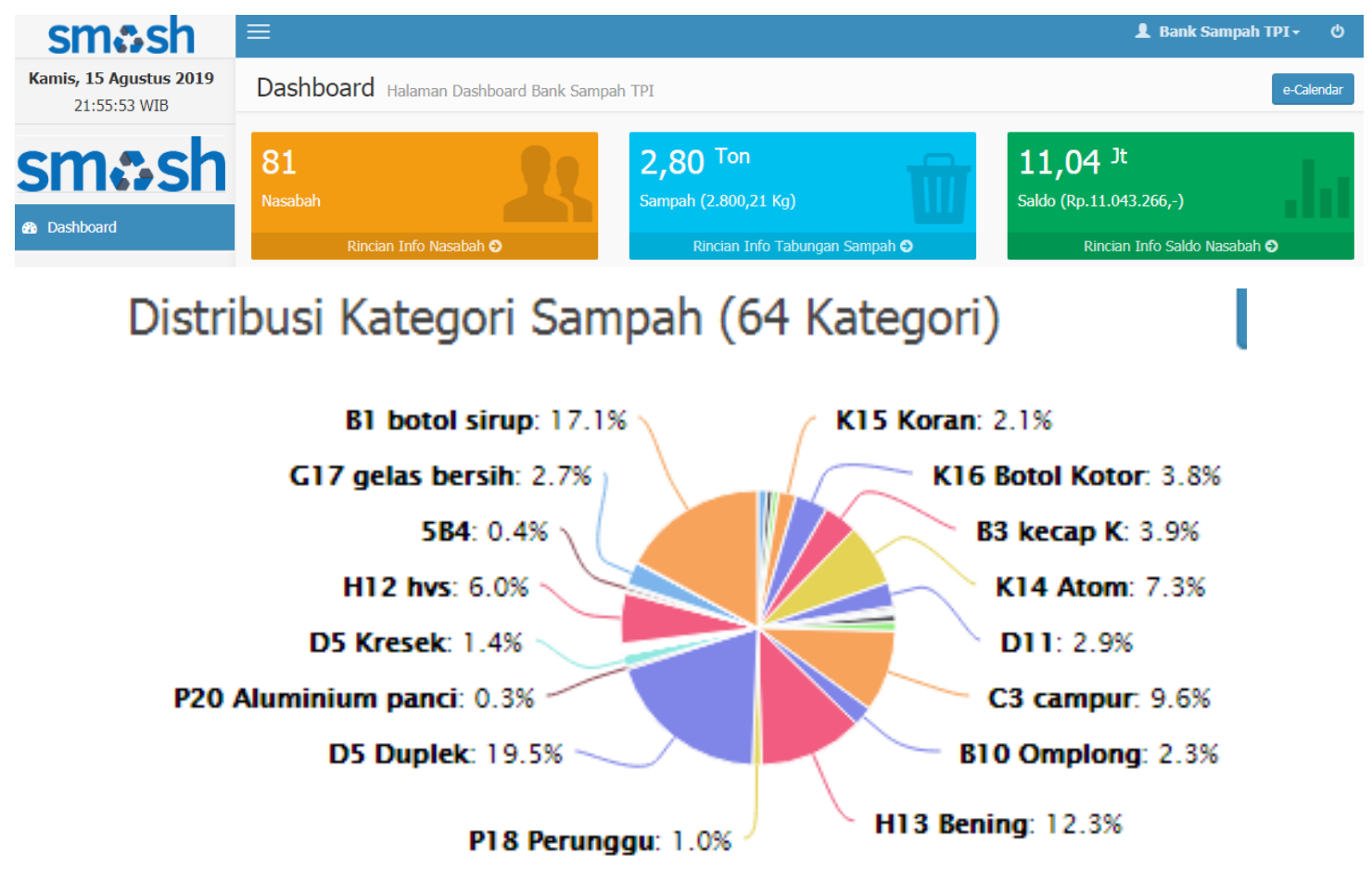

Sumber: Tim PKM UYP 2019

\section{Pembahasan}

Sebagai upaya untuk mendorong keterlibatan multipihak dalam penanganan sampah,sejak tahun 2016Pemerintah Kabupaten Pasuruan telah menginisiasi pembentukan Bank Sampah di tiap desa melalui program Satu Desa Satu Bank Sampah (SDSB). Dimana hingga tahun 2019 ini telah terbentuk 145 bank sampah yang tersebar di 20 kecamatan. ${ }^{4}$ Pada tahun 2018 juga telah dibangung TPA terpadu di desa Wonokerto Kecamatan Sukorejo. ${ }^{5}$ Adapun pada tahun 2019 ini akan dibangun enam unit TPS3R dengan perincian satu titik masing-masing di kecamatan Puspo, Pohdjentrek, Beji, dan Purwosari, dan dua

\footnotetext{
${ }^{4}$ Dinas Lingkungan Hidup, Data Banks Sampah Kabupaten Pasuruan, 2019.

5https://news.detik.com/berita-jawa-timur/d-3578908/program-sdsb-kurangi-40-persen-sampah-dikabupaten-pasuruan
} 
12 | Modernisasi Manajemen Bank Sampah...

titik di kecamatan Prigen. ${ }^{6}$

Upaya-upaya tersebut ternyata dalam realitasnya belum mampu menyelesaikan segala permasalahan sampah di kabupaten Pasuruan, karena inisiasi pendirian bank sampahnya masih dilakukan secara Top Down dan model penanganannya juga masih bersifat Open Dumping. Selain itu juga orientasi utama di masing-masing bank sampah masih didominasi oleh orientasi ekonomi murni. Ada satu komunitas berbasis sekolah yang sudah mampu berinovasi dengan mendesain ulang pengelolaan sampah dengan konsep "shodaqoh sampah”. Inovasi ini telah dilakukan oleh PAUD Wanjati Pandaan Pasuruan, dimana anak-anak secara langsung diajari mengenal dan memilah sampah serta dan mengenalkan sampah-sampah yang bernilai untukdishodaqohkan.Melalui program ini, anak usia dini terbangun wawasan pengetahunnya dan memiliki kesadaran serta kepedulian akan lingkungan yang bersih dengan tidak membuang sampah di sembarang tempat dan mampu memanfaatkan sampah di sekitar rumah mereka. Program shodaqohsampah ini dilakukan setiap hari Rabu dansudah berjalan sejak awal berdirinya Pos PAUD Wanjati Junior. ${ }^{7}$

Berbeda dengan Bank Sampah TPI BISA ini yang memang dari awal berdirinya bersifat Bottom $U p$ dimana berdirinya merupakan hasil dari kegelisahan para ibu rumah tangga atas permasalahan sampah di kawasan perumahan Taman Permai Indah. Selain itu juga dalam pengelolaannya sudah menggunakan metode 3R (Reduce, Reuse, dan Recycle).

Secara kontekstual di lapangan, tahapan-tahapan yang telah dilakukan oleh Bank Sampah TPI BISA mengacu pada Peraturan Daerah Kabupaten Pasuruan Nomor 3 Tahun 2010 tentang pengelolaan sampah,yang terdiri dari empat tahapan: (1) Pengumpulan sampah, (2) Pemilahan Sampah, (3)

${ }^{6}$ https://www.bangsaonline.com/berita/61649/tps-sampah-kabupaten-pasuruan-overload-pemkabberharap-program-sdsb-jadi-solusi

${ }^{7}$ Fathurrohman, A., Dayat, M., Apriwiyanto, S. S., \& Wibisono, M. (2018). Shodaqoh Sampah Usia Dini: Implementasi Program Shodaqoh Sampah pada Pendidikan Usia Dini Wanjati Junior Pandaan Pasuruan. PROCEEDINGS: Annual Conference for MuslimScholars, 1(Series 2), 711-720 
Pengangkutan Sampah, dan (4) pengolahan sampah.

Pada tahap pengumpulan sampah, terdapat dua cara yakni dengan dikumpulkan sendiri oleh para nasabah/warga dan dikoordinir tiap RT. Dalam pengumpulan sampah secara mandiri, warga/ nasabah mengumpulkan sampah di rumah masing-masing dan disetorkan kepada pengurus bank sampah sewaktuwaktu. Adapun nasabah yang mengumpulkan sampah secara berkelompok, pengumpulannya dikoordinir oleh pengurus RT setempat. Cara ini untuk memudahkan nasabah dalam pengumpulan sampahnya karena yang bersangkutan sehari-harinya mempunyai kesibukan/kerja.

Pada tahap pemilahan sampah, prosesnyameliputi (a) Sampah dikumpulkan ditempat yang sudah disediakan; (b) Sampah yang sudah terkumpul kemudian dibersihkan; (c) Sampah yang sudah dibersihkan kemudian dipilah; (d) Sampah yang sudah dipilah kemudian ditimbang sesuai jenisnya. Pemilahan sampah ini dilakukan dengan tujuan supaya tidak tercampur satu dengan yang lain, sehingga dapat mempengaruhi harga yang dihasilkan. Selai itu juga karena ada beberapa jenis sampah yang tidak dijual langsung, akan tetapi dibuat kerajinan tangan (Hand Craft). Pemilahan sampah tersebut dilakukan ditempat pengumpulan sampah yakni gardu/pos jaga tempat pengumpulan sampah yang berdekatan dengan rumah ibu Dewi selaku ketua bank sampah TPI yang juga sebagai kantor pengurus bank sampah.

Sebagaimana hasil studinya Wahyono $(2011)^{8}$, sampah dipilah sesuai jenisnya yakni sampah organik dan sampah anorganik. Sampah organik adalah sampah yang berasal dari sisa-sisa makanan, buah-buahan, sayur daun dan lain sebagainya. Sampah organik sebagian oleh pengurus dimanfaatkan menjadi kompos. Yang tergolong sampah an-organik adalah sampah botol, plastik, kresek, kertas, besi, alumunium dan lain sebagainya. Selain sampah an-organik yang bisa dimanfaatkan, ada juga sampah yang tergolong an-organik yang tidak

\footnotetext{
${ }^{8}$ Wahyono, S. (2011). Pengolahan sampah organik dan aspek sanitasi. Jurnal Teknologi Lingkungan,
} 2(2), 113-118. Retrieved from http://www.kelair.bppt.go.id/Jtl/2001/vol2-2/01organik.pdf 
14 | Modernisasi Manajemen Bank Sampah...

bisa dimanfaatkan seperti sampah pampers/popok bayi, pembalut wanita dan streofom (B3). Lebih spesifik sampah yang dipilah ditempat pemilahan adalah sampah yang tergolong an-organik kecuali sampah B3.

Pada tahap pengangkutan sampah, sampah dilingkungan perumahan Taman Permata Indah diawal-awal pendirian bank sampah TPI dilakukan dengan cara manual atau dibawah langsung oleh nasabah untuk dikumpulkan ke pengurus bank sampah. fenomena tersebut diakibatkan kurangnya fasilitas yang mendukung kegiatan untuk pengangkutan sampah dari sumber sampah kepada pengurus bank sampah.Seiring berjalannya waktu pengurus bank sampah mempunyai inisiatif untuk jemput bola untuk mengambil sampah yang akan disetorkan dengan bekerja sama dengan biro kebersihan perumahan yang dibayar melalui iuran kas kebersiahan bulanan dengan menggunakan mobil bak terbuka untuk mengangkut sampah.

Sejak tahun 2018 Bank Sampah TPI BISA sudah memiliki Armada Motor Tosa hasil bantuan dari DLH Kabupaten Pasuruan. Sehingga pengurus lebih mobile dan efisien dalam mengatur penjadwalan penjemputan sampah dan penjualan sampah kering ekonomis ke pengepul sampah.

Adapun pada tahap pengolahan sampah, pengolahannya dilakukan oleh pengurus dirumah ibu Dewi yang juga difungsikan sebagai kantor bank sampah TPI dengan melibatkan seluruh pengurus bank sampah. Sampah yang sudah terkumpul tidak lantas langsung disetorkan kepada pengepul, akan tetapi ada beberapa jenis sampah yang memang sengaja dipilah untuk dijadikan kerajinan tangan. Ada beberapa jenis sampah yang biasa dibuat kerajianantangan , antara lain: lingkaran sisa gelas minuman yang terbuat dari plastik, tutup galon, kertas semen, kresek bekas, bungkus permen atau snack, dan lain-lain.

Seperti penuturan dari Ibu Dewi selaku ketua pengurus bahwa dari hasil kerajinan tangan tersebut, pengurus mendapatkan hasil yang lumayan daripada langsung disetor ke pengepul. Sampah sisa kerajinan dijadikan satu dengan sampah yang sudah dipilah kemudian disetorkan untuk dijual ke pengepul. 
Khusus untuk sampah yang tidak bisa dimanfaatkan lagi seperti sampah pampers/popok bayi, pembalut dan streoform akan ditimbun ditempat penimbunan.

Adapun pendampingan modernisasi manajemen bank sampah denganpemanfaatan aplikasi SMASH bank sampah dan www.banksampah.id pada Komunitas Bank Sampah TPI BISA selama 3,5 bulan mulai bulan Mei Agustus 2019 telah mampumerevitalisasi pengelolaan sampah dengan hasil capaian diantaranya: (1) Adanya komitmen dan keterlibatan aktif baik dari pengurus maupun nasabah Bank Sampah TPI BISA dalam merevitalisasi bank sampah berbasis IT; (2) Telah terlaksananya kegiatan capacity buildingpada penguatan skillbagi pengurus dan nasabah dalam pemanfaatan aplikasi berbasis IT guna menunjang performa Bank Sampah TPI BISA; (3) Bank Sampah TPI BISA sudah memiliki akun aplikasi bangsampah SMASH dan www.banksampah.id serta pengurus sudah mampu melakukan unggah data kegiatan transaksi bank sampah TPI BISA dan 70\% sudah terupload kedalam sistem aplikasi bank sampah; (4) Bank Sampah TPI BISA sudah memiliki website dengan nama www.bstpibisa.com serta pengurus bank sampah sudah mempunyai kemampuan dalam pengelolaan website untuk menunjang informasi dan performa komunitas bank sampah TPI BISA.

\section{Kesimpulan}

Program Modernisasi Manajemen Bank Sampah Melalui Pemanfaatan Aplikasi Bank Sampah IT Mobile Pada Komunitas Bank Sampah TPI BISA Kelurahan Pagak Kec. Beji Kab. Pasuruan ini telah dilaksanakan selama 3,5 bulan mulai bulan Mei sampai Agustus 2019. Kegiatan ini telah memberikan pengetahuan dan skill baru kepada komunitas Bank Sampah TPI BISA terkait skill penggunaan aplikasi bank sampah berbasis android yaitu SMASH bank sampah serta bank sampah berbasis website yaitu www.banksampah.id. Selain itu pengurus bank sampah TPI BISA juga telah memiliki website sebagai media informasi 
16 | Modernisasi Manajemen Bank Sampah...

kegiatan serta penjualan hasil kerajinan berbahan sampah dengan nama www.bstpibisa.com. Melalui upaya ini Bank Sampah TPI BISA diharapkan menjadi bank sampah pionir dikabupaten Pasuruan yang mampu memanfaatkan perkembangan teknologi dalam kegiatan pengelolaan sampah. Kesuksesan pelaksanaan program ini, tentunya tidak bisa dipungkiri dari adanya keterlibatan berbagai elemen masyarakat khususnya warga perumahan permata indah serta aparatur Kelurahan Pagak serta berbagai pihak terkait seperti Universitas Yudharta Pasuruan.

Untuk mendorong keberlanjutan dan kesuksesan program penanganan sampah di kawasan perumahan Taman Permata Indah kelurahan Pagak kecamatan Beji kabupaten Pasuruan maka perlu adanya penguatan beberapa hal yaitu : (1). Penguatan struktur bank sampah dengan melibatkan generasi muda.Regenerasi / pengkaderan dengan melibatkan remaja di Perumahan Permata Indah sangat diperlukan mengingat pengurus dalam komunitas Bank Sampah TPI BISA saat ini didominasi oleh ibu-ibu dengan usia relatif tua sehingga penguasaan pengoperasian website sementara ini masih bertumpu pada 2 orang pengurus saja. (2). Bersinergi dengan pemerintah desa/kelurahan.Upaya ini penting dilakukan karena dengan melakukan sinergi dengan pemerintah desa setidaknya akan mampu mendorong desa untuk memberikan dukungan secara nyata melalui dukungan anggaran serta kebijakan bisa dalam bentuk peraturan desa tentang tatakelola sampah sehingga keberadaan bank sampah semakin kuat dimasyarakat. 


\section{Daftar Pustaka}

Badan Lingkungan Hidup. (2017). Perhitungan Timbulan Sampah Kabupaten Pasuruan.Kabupaten Pasuruan.

Bupati Pasuruan. Peraturan Daerah Kabupaten Pasuruan Nomor 3 Tahun 2010 TentangPengelolaan Sampah Di Kabupaten Pasuruan, Pub. L. No. 3, 1 (2010). Indonesia.

Dinas Lingkungan Hidup, Data Banks Sampah Kabupaten Pasuruan, 2019.

Fahmi, Muhammad, (2018) "Sehari, Produksi Sampah di Kabupaten Pasuruan Capai4.700 Meter Kubik” https://radarbromo.jawapos.com/read/2018/03/12/56305/sehariproduksisampah-di-kabupaten-pasuruan-capai-4700-meter-kubik (diakses tanggal 09Agustus 2018)

Fathurrohman, A., Dayat, M., Apriwiyanto, S. S., \& Wibisono, M. (2018). ShodaqohSampah Usia Dini: Implementasi Program Shodaqoh Sampah pada Pendidikan Usia DiniWanjati Junior Pandaan Pasuruan. PROCEEDINGS: Annual Conference for MuslimScholars, 1(Series 2), 711-720.

https://news.detik.com/berita-jawa-timur/d-3578908/program-sdsb-kurangi-40persen sampah-di-kabupaten-pasuruan

https://www.bangsaonline.com/berita/61649/tps-sampah-kabupaten-pasuruanoverload-pemkab-berharap-program-sdsb-jadi-solusi

Pemkab Pasuruan, (2016) “Tuntaskan Tpa Kenep, Bebaskan 2250 M2 Lahan"https://www.pasuruankab.go.id/berita-2077-tuntaskan-tpa-kenepbebaskan-2250-m2-lahan.html. (diakses tanggal 09 Agustus 2018)

Wahyono, S. (2011). Pengolahan sampah organik dan aspek sanitasi. Jurnal TeknologiLingkungan, 2(2), 113-118. Retrieved from http://www.kelair.bppt.go.id/Jt1/2001/vol2-2/01organik.pdf 
18 | Modernisasi Manajemen Bank Sampah... 